\title{
Sobriedade e embriaguez: a luta dos soldados de Cristo contra as festas dos tupinambás*
}

João Azevedo Fernandes ${ }^{* *}$

O artigo analisa a luta dos missionários cristãos, em especial os jesuítas, contra as festas e as bebidas alcoólicas dos tupinambás. Eles perceberam que, nestas festas, a cultura tupinambá, principal obstáculo à evangelização, se renovava e se reafirmava constantemente. O artigo também explora as principais estratégias usadas pelos europeus para alcançar o objetivo de extinguir as festas dos índios.

Palavras-chave: Festas - Álcool e Embriaguez - Jesuítas

Sobriety and drunkenness: the fight of soldiers of Christ against the feasts of tupinamba

The article analyzes the fight of the Christian missionaries, specially the Jesuits, against the feasts and the alcoholic beverages of tupinambas. The missionaries had realized that in these parties, the tupinamba culture, main obstacle to Christian evangelism, was constantly renewed and reaffirmed. The article also explores the main strategies used for the Europeans to reach the objective of extinguishing the feasts of Brazilian Indians.

Keywords: Feasts - Alcohol and Drunkeness - Jesuits

\footnotetext{
"Artigo recebido em outubro de 2006 e aprovado para publicação em dezembro de 2006.

** Professor do Departamento de História da Universidade Federal da Paraíba. E-mail: joaser@uol.com.br.
} 


\section{Sobriété et griserie: le combat des soldats du Christ contre les fêtes des tupinambás}

Cet article analyse les efforts des missionnaires chrétiens, en particulier les jésuites, pour contrer les fêtes et les boissons alcooliques des Tupinambás. Les missionnaires se sont aperçus que, dans ces fêtes, la culture tupinambá, principal obstacle à l'évangélisation chrétienne, se renouvelait et réaffirmait incessamment. L'article parcourt aussi les principales stratégies employées par les européens afin d'anéantir les fêtes indiennes.

Mots-clés: Fêtes - Alcool et Ivresse - Jésuites

É esta gente tanto mais fácil em aceitar a fé do verdadeiro Deus, quanto menos empenhada está com os falsos; porque nenhum conhece, ou ama, que possa roubar-lhe a afeição. Seus ídolos são os ritos avessos de sua gentilidade, multidão de mulheres, vinhos, ódios, agouros, feitiçarias, e gula de carne humana; vencidos estes, nenhuma repugnância lhes fica para as coisas da fé (....). ${ }^{1}$

Ao aportar no novo mundo do Brasil, em 29 de março de 1549, depois de dois meses de viagem, o jesuíta Manuel da Nóbrega estava muito otimista. Ao que tudo indicava, seu único problema seria tratar com os povoadores portugueses, cerca de cinqüenta pessoas, que viviam, em sua maioria, em "hum grande peccado", que era "terem os homens quasi todos suas negras por mancebas, e outras livres que pedem aos negros por molheres, segundo ho custume da terra, que hé terem muitas molheres". ${ }^{2}$ Quanto aos "negros", isto é, os índios, apesar de serem "gente ton inculta e que tan poco lo conosce" e se regerem "por inclinación (...) e por apetite sensual", ${ }^{3}$ possuíam uma enorme -e decisiva - qualidade: era "gente que nenhum conhecimento tem de Deus, nem idolos" e que "fazem tudo quanto lhe dizem".

\footnotetext{
${ }^{1}$ Simão de Vasconcelos, Crônica da Companhia de Jesus, $3{ }^{\text {a }}$ edição, Petrópolis, Vozes/Brasília, INL, 1977 ( $1^{\text {a }}$ edição 1663), v. II, p. 15.

${ }^{2}$ Carta do Pe. Manuel da Nóbrega ao Pe. Simão Rodrigues, Lisboa (Bahia, 09/08/1549), Serafim Leite, Cartas dos Primeiros Jesuitas do Brasil, Coimbra, Tipografia da Atlântida/Comissão do IV Centenário da Cidade de São Paulo, 1954, v. I, p. 119.

${ }^{3}$ Carta do Pe. Manuel da Nóbrega ao Dr. Martín de Azpilcueta Navarro, Coimbra (Salvador [Bahia], 10/08/1549), Leite, op. cit., v. I, p. 136.

${ }^{4}$ Carta do Pe. Manuel da Nóbrega ao Pe. Simão Rodrigues, Lisboa (Bahia, 10/04/1549), Leite, idem, v. I, p. 111.
} 
Não encontrando, entre os índios no Brasil, os templos, os sacerdotes e os ídolos com os quais se deveriam defrontar e, gloriosamente, derrotar, ${ }^{5}$ os inacianos sentiram-se livres para tratar os índios como o genus angelicum das profecias milenaristas que os inspiraram, um povo virgem sobre o qual seria possível refundar o mundo cristão. De todo modo, era necessário imputar-lhes algum tipo de "crença", de "falsa religião" com a qual se pudesse estabelecer um diálogo epistemológico com base na dicotomia verdadeirolfalso, o que foi feito ao se conceder o estatuto de "sacerdotes" do demônio aos caraíbas - os pajés nômades dos tupinambás - e a seus rituais, o epíteto de santidades, a falsa religião que deveria ser derrotada pelo Deus da verdade e por seus soldados. ${ }^{6}$

Seria ocioso retomar, neste artigo, a discussão acerca da luta dos jesuítas contra a "religião" ou "falta de religião" dos tupinambás, tema admiravelmente trabalhado por autores como Eduardo Viveiros de Castro, Ronaldo Vainfas e Cristina Pompa. O meu interesse será perceber como as riquíssimas tradições e práticas etílicas dos tupinambás foram combatidas pelos jesuítas (e por missionários de outras ordens que, de forma deliberada ou não, tomaram os inacianos como modelo para o seu próprio proselitismo), no contexto de sua luta contra os "maus costumes" dos índios.

Assim como outros povos indígenas, os tupinambás possuíam um sólido conhecimento das artes da fermentação e utilizavam este conhecimento em uma pletora de bebidas fermentadas chamadas genericamente de $\mathrm{cauim}^{7} \mathrm{em}$ especial as cervejas de mandioca e milho e os vinhos de frutas, dos quais o mais apreciado era o de caju. Estas bebidas não eram usadas no dia-a-dia, sendo consumidas em grandes festas, as cauinagens, que reuniam membros de vários grupos locais, com o objetivo de comemorar casamentos e passagens dos jovens à idade adulta, chorar os mortos nos funerais, decidir sobre a conveniência de

\footnotetext{
${ }^{5}$ Ronaldo Vainfas, A Heresia dos Índios: catolicismo e rebeldia no Brasil colonial, São Paulo, Companhia das Letras, 1995, p. 28-29.

${ }^{6}$ Cristina Pompa, Religião como Tradução: missionários, Tupi e Tapuia no Brasil colonial, Bauru, Edusc/Anpocs, 2003, p. 35-56.

${ }^{7} \mathrm{O}$ significado de "cauim" é controverso. Os dicionaristas afirmam que a palavra significa "bebida fermentada" (Aurélio) ou "bebida qualquer" (Houaiss). Alguns autores, como Rodolfo Garcia, relacionam "cauim" a acayu-y, ou "água de caju”, o que faz referência a uma das bebidas preferidas dos índios. De minha parte, fico com a tradução de Ermano Stradelli (Vocabulário Nhê̂ngatú, 1929), que prefere $c a$ 'o-y, ou "água do bêbado", usado para qualquer bebida espirituosa, daí as palavras caoy-ayáb ("cauim azedo") e caoy-piranga ("cauim vermelho"), com as quais os índios designavam o vinho dos europeus, ou caoy-tatá ("cauim de fogo"), usado para a aguardente.
} 
fazer a guerra, recepcionar visitantes ilustres (como os pajés itinerantes, os caraíbas) e, especialmente, realizar aquele que era o rito central da sociedade tupinambá: a morte e a devoração dos inimigos capturados.

As cauinagens representavam um espaço crucial para o exercício das relações sociais mediadas pela hospitalidade, para a demonstração de poder dos grupos que ofereciam as bebidas para as festas, para a reunião de homens para o trabalho em grupo (como no caso do corte e da queima de matas para o cultivo de alimentos) e para a expressão ritual das contradições e complementaridades que marcavam as relações de gênero entre os tupinambás. O cauim representava, para os índios, uma "cultura material corporificada", uma matéria-prima carregada de simbolismo que, ao ser ingerida coletivamente, permitia que a economia doméstica se articulasse à política, e que as técnicas corporais (como a forma de manejar a embriaguez) se tornassem veículos para a efetivação das identidades nativas vis-à-vis o impacto da chegada dos europeus.

Faltando a religião, deveriam os soldados de Cristo lutar contra as "gentilidades" - a poligamia, o canibalismo, a nudez, as bebedeiras... -, trazendo os bárbaros à civilização. Somente após a transformação daqueles seres vistos, alternativamente, como "infantis" ou "bestiais" - em homens, em seres "policiados" e "reduzidos" (pelo controle de corpos e mentes), poderiam eles chegar à condição de súditos, sujeitos a um padre, a um rei, a um Deus. Não perceberam (ou não puderam perceber) os jesuítas que os tais "maus costumes" e "gentilidades" eram "sua verdadeira religião, e que sua inconstância era o resultado da adesão profunda a um conjunto de crenças de pleno direito religioso". 9

\footnotetext{
${ }^{8}$ Michael Dietler, "Theorizing the feast: rituals of consumption, commensal politics, and power in african contexts", Michael Dietler e Brian Hayden (ed.), Feasts: archaeological and ethnographic perspectives on food, politics, and power, Washington/Londres, Smithsonian Institution Press, 2001, p. 65-114. Trabalhei exaustivamente com as formas de produção e consumo do cauim entre os tupinambás em minha tese de doutoramento, "Selvagens Bebedeiras: Álcool, Embriaguez e Contatos Culturais no Brasil Colonial”, Niterói, PPGH/Universidade Federal Fluminense, 2004. Ver também, acerca do cauim e das cauinagens (entre outros), Luís da Câmara Cascudo, História da Alimentação no Brasil, $3^{\text {a }}$ edição, São Paulo, Global Editora, 2004, p. 129-141; e Ronald Raminelli, "Da etiqueta canibal: beber antes de comer”, Renato Pe. Venâncio e Henrique Carneiro (org.), Álcool e drogas na história do Brasil, São Paulo, Alameda/Belo Horizonte, PUC/Minas, 2005, p. 29-46.

${ }^{9}$ Eduardo Viveiros de Castro, "O mármore e a murta: sobre a inconstância da alma selvagem", p. 192, A inconstância da alma selvagem - e outros ensaios de antropologia, São Paulo, Cosac \& Naify, 2002, p. 183-264.
} 
Era a religião da guerra, mas não como simples belicosidade, ${ }^{10} \mathrm{e}$ sim como devir histórico: os tupinambás matavam os inimigos (e eram mortos por eles) para manter em funcionamento um ciclo infindo de vinganças, ciclo que constituía sua própria memória. Memória que era permanentemente atualizada nos discursos e nas perorações dos "senhores da fala", dos grandes guerreiros a cantarem seus feitos, e de seus antepassados, pelas madrugadas das aldeias, durante os rituais do sacrifício canibal e, notadamente, durante as cauinagens, "a suma festa deste gentio", como disse Jácome Monteiro, na qual somente se ouvia "a prática da guerra, como mataram, como entraram na cerca dos inimigos, como lhe quebraram as cabeças. Assim que os vinhos são os memoriais e crónicas de suas façanhas"."11

"Os memoriais e crónicas de suas façanhas..." Se a religião dos tupinambás era a sua crônica de vinganças, de inimigos devorados e de crânios estraçalhados, as cauinagens eram o seu templo e, se os índios não tinham templos de pedra a serem destruídos, tinham os "vinhos" a serem extirpados, por cumprirem estes a mesma função que, entre os pagãos idólatras, cumpriam aqueles. Como aponta Eduardo Viveiros de Castro, “os tupinambás bebiam para não esquecer, e aí residia o problema das cauinagens, grandemente aborrecidas pelos missionários, que percebiam sua perigosa relação com tudo aquilo que queriam abolir". ${ }^{2}$

Não se deve deixar de apontar a extraordinária capacidade dos jesuítas de se adaptarem às condições locais e de criarem formas de luta apropriadas a pagãos que não possuíam, ou que aparentavam não possuir, religiões organizadas às quais os inacianos pudessem contrapor-se. A mais importante destas adaptações foi, sem dúvida, a criação dos aldeamentos, instituição que estava em contradição direta com o espírito da "catequese itinerante", que constituía a norma da ação jesuítica na Europa.

É claro que os jesuítas no Brasil estavam conscientes desta contradição, mas os aldeamentos pareciam ser o único meio de arrancar os nativos do ambiente (as aldeias) propício aos "maus costumes" e, principalmente, retirá-los do convívio com os colonos leigos, somente interessados em escravizá-los, em

\footnotetext{
${ }^{10}$ E nem como base para uma vingança relacionada a um "culto dos ancestrais", como quis Florestan Fernandes: A Função Social da Guerra na Sociedade Tupinambá, São Paulo, Pioneira/Edusp, 1970.

${ }^{11}$ Jácome Monteiro, "Relação da província do Brasil, 1610", p. 410; Serafim Leite, História da Companhia de Jesus no Brasil, Rio de Janeiro, Civilização Brasileira, 1949, v. VIII, p. 393 425.

${ }^{12}$ Viveiros de Castro, op. cit., p. 248.
} 
se amancebar com suas mulheres e - na contramão de uma suposta "aculturação" - participar de seus costumes e aceitá-los, entre eles as cauinagens, como ocorria com os mamelucos e mesmo com os reinóis. ${ }^{13}$

Deve ser notado, por outro lado, que os jesuítas traziam da Europa toda uma informação relativa à luta de outras ordens religiosas contra a embriaguez e os regimes etílicos dos nativos americanos, e as implicações e conexões destes regimes para as religiões e os sistemas de pensamento dos índios, com os quais os missionários cristãos tinham que lidar. O exemplo da Nova Espanha (México) rapidamente se nos apresenta, e isto por vários motivos, não sendo o menor o fato de que alguns dos inacianos que vieram para o Brasil, como José de Anchieta ou Azpilcueta Navarro, eram espanhóis e foram formados como religiosos na Espanha.

Para além das origens individuais, portugueses e espanhóis possuíam regimes etílicos praticamente idênticos, compartilhando visões semelhantes a respeito do ato de beber, e daquilo que deveria ser feito para extirpar os maus atos etílicos dos nativos, na busca de transformá-los em verdadeiros cristãos e homens "civilizados". E o mais importante: em ambos os casos coloniais, uma impressão inicial de otimismo quanto à evangelização daqueles povos transformou-se em uma visão pessimista, de uma América atolada no pecado e na presença do Diabo, modificação de perspectiva para a qual concorreu decididamente a dificuldade em extirpar a prática do "beber supérfluo". ${ }^{14}$

Os missionários que exerceram seu ministério no México desenvolveram toda uma reflexão acerca do pecado da embriaguez que, provavelmente, influenciou de alguma forma a mentalidade dos jesuítas no Brasil, embora este seja um fato de difícil análise, até mesmo por conta do caráter relativamente iliterato da colonização portuguesa, como bem disse Sérgio Buarque de Holanda.$^{15}$ Ao chegarem os jesuítas ao Brasil, em 1549, já haviam sido publicadas obras como as várias Doctrinas de Juan de Zumárraga (primeiro bispo do México, inquisidor e grande "caçador" de bruxas), Alonso de Molina e Pedro de Córdova, que propunham as linhas de atuação para a evangeliza-

\footnotetext{
${ }^{13}$ Pompa, op. cit., p. 68-69.

${ }^{14}$ Sobre esta modificação no México, cf. Sonia C. de Mancera, El fraile, el indio y el pulque: Evangelización y embriaguez en la Nueva España (1523-1548), México (D. F.), Fondo de Cultura Económica, 1991, p. 239-256.

${ }^{15}$ Sérgio Buarque de Holanda, Caminhos e Fronteiras, $3^{\text {a }}$ edição, São Paulo, Companhia das Letras, 1994 (1 ${ }^{\text {a }}$ edição: 1956), p. 61-87.
} 
ção dos povos nativos do México, e que davam especial atenção ao pecado da embriaguez. ${ }^{16}$

A par destas prováveis influências, os jesuítas no Brasil estavam, certamente, em contato com as reflexões acerca da embriaguez, feitas pelo respeitado teólogo espanhol Martín de Azpilcueta Navarro (1491-1586), correspondente de Manuel da Nóbrega - que havia sido seu aluno em Coimbra e do qual havia recebido o grau de Bacharel em Cânones, em $1541^{17}$ - e que era tio de um de seus companheiros de viagem e de missão, o padre Juan de Azpilcueta Navarro (1521?-1557). ${ }^{18}$

O doutor Navarro era uma forte influência para os evangelistas mexicanos, sendo autor de uma das mais aceitas definições acerca do pecado da embriaguez, que estava perfeitamente de acordo com a prática ibérica de consumo quotidiano e moderado do vinho, enquanto parte das refeições e da nutrição quotidiana. Para Navarro, só havia pecado se houvesse premeditação na embriaguez, se o indivíduo bebia "conociendo que se había de embeodar, se hizo daño a sí mismo o a otro, privándose del uso de la razón. Si bebió sin creer que se iba a embeodar, no hay pecado mortal". ${ }^{19}$

É importante, a partir destes pontos de contato, traçar um paralelo entre os processos de evangelização no Brasil e no México, mas também é necessário apontar os contrastes entre os regimes etílicos nativos das duas regiões. As grandes e complexas civilizações nativas da Mesoamérica possuíam formas de relacionamento com a bebida e a embriaguez que refletiam diretamente a profunda hierarquização e estratificação de seus sistemas sociais, e que as diferenciavam bastante de sociedades relativamente igualitárias como a dos tupinambás.

No México, os espanhóis encontraram bebidas nativas que eram cruciais para a economia e a religião dos indígenas. O pulque, fermentado a partir da seiva do agave,$^{20}$ estava associado ao culto de várias divindades, como Mayáhuel (humana divinizada como deusa da fertilidade e da seiva não-fermentada) e Pahtécatl (também um herói cultural divinizado, inventor e senhor da fermen-

${ }^{16}$ Mancera, op. cit., p. 154-160.

17 Serafim Leite, em nota à Carta do Pe. Manuel da Nóbrega ao Dr. Martín de Azpilcueta Navarro, Coimbra (Salvador [Bahia], 10/08/1549), Leite, 1954, op. cit., v. I, p. 134.

${ }^{18}$ Leite, idem, v. I, p. 38.

${ }_{19}$ Martín de Azpilcueta Navarro, apud Sonia C. de Mancera, Del amor al temor: Borrachez, catequesis y control en la Nueva España (1555-1771), México (D. F.), 1994, Fondo de Cultura Económica, p. 53.

${ }^{20}$ Oswaldo G. de Lima, El maguey y el pulque en los códices mexicanos, $2^{\mathrm{a}}$ edição, México (D. F.), Fondo de Cultura Económica, 1986 (1 ${ }^{\text {a }}$ edição: 1956), p. 13-14; Mancera, 1991, op. cit., p. 20. 
tação), entre outros. O pulque também era consumido em rituais de sacrifício humano, assim como representava um importante item dos impostos cobrados aos povos submetidos ao domínio Asteca.

De maneira geral, não era permitido aos homens comuns um contato livre, não mediado pelas autoridades religiosas, com a esfera divina. Sendo o pulque apanágio de uma série de divindades, ingeri-lo significava obter acesso a um tipo de possessão mística que estava vedada aos homens comuns, os macehuales. Contudo, existiam numerosos festivais e ritos religiosos em que estas proibições ficavam relaxadas, e nos quais todos acabavam por encontrar oportunidades de escapar aos rígidos controles impostos pelas normas sociais. ${ }^{21}$

Afora estas ocasiões, as sociedades do México central tendiam a reprimir e a ver com maus olhos a embriaguez, possuindo várias instâncias formais e informais nas quais o excesso no beber era punido, com maior ou menor severidade. O Códice Florentino ${ }^{22}$ é pródigo em demonstrações de desagrado contra a embriaguez desmedida, como é o caso da história de Cuextécatl, verdadeiro "mito de origem" de todo o mal que poderia ser provocado pela embriaguez:

E um homem de nome Cuextécatl / rei de um povo numeroso / que bebeu somente quatro (jarras) / depois que já havia bebido quatro / exigiu uma mais / e bebeu a quinta (jarra) / por isso ficou totalmente ébrio, totalmente bêbado / e não sabia como deveria se comportar / e ali, diante do povo se despiu / porque estava completamente ébrio... ${ }^{23}$

Em um trecho deste códice, os antigos mexicanos revelam com clareza sua visão acerca da ebriedade, ao dizer que o pulque:

(...) é raiz e princípio de todo o mal e de toda a perdição porque este octli ${ }^{24} \mathrm{e}$ esta embriaguez são causa de toda a discórdia e dissensão e de todas as re-

\footnotetext{
${ }^{21}$ William B. Taylor, Drinking, Homicide and Rebellion in Colonial Mexican Villages, Stanford, Stanford University Press, 1979, p. 30.

${ }^{22}$ Conjunto de mitos recolhidos pelo missionário Bernardino de Sahagún, e no qual está descrita a penosa migração que trouxe os "bárbaros" ancestrais dos astecas ao México central, vindos do norte desértico.

${ }^{23}$ Poema "Mexica" de origem do pulque e da embriaguez, Oswaldo G. de Lima, Pulque, Balché y Pajauaru. En la etnobiología de las bebidas y de los alimentos fermentados, $2^{\text {a }}$ edição, México (D. F.), Fondo de Cultura Económica, 1990 (1 ${ }^{a}$ edição: 1975), p. 148. Existe aqui um paralelismo muito interessante com o mito de Noé, já que Cuextécatl também se despe e revela seus órgãos sexuais, assim como fez o patriarca bíblico.

${ }^{24}$ Nome asteca do pulque.
} 
voltas e desassossegos dos povos e reinos: é como um torvelinho que a tudo revolve e desbarata, é como uma tempestade infernal que traz consigo todos os males juntos. ${ }^{25}$

Percebe-se, portanto, que, apesar de todas as suas diferenças com os europeus, os índios mexicanos possuíam sua própria ideologia antialcoólica, tão complexa, aliás, quanto aquela formulada pelo cristianismo, o que os afastava bastante da visão tupinambá acerca do álcool. Apesar disto, tanto astecas quanto tupinambás, guardadas as diferenças, possuíam uma forma de embriaguez ritual, de possessão divina, que, no entender dos cristãos, igualava seus regimes etílicos enquanto espaços para a ação do "demônio" e enquanto esferas da vida nativa que deveriam ser extirpadas pela ação missionária. Tanto espanhóis quanto portugueses procuraram reprimir estas formas religiosas de embriaguez a partir de um ponto de vista que vê na ebriedade um atentado à temperança, noção central no cristianismo pós-tomista.

Durante o século XVI, desenvolveu-se na Europa católica uma visão do bêbado como alguém que tem sua razão ofuscada pelos vapores da bebida, e que se põe a rir com liberdade e sem controle, desrespeitando a autoridade que o observa, vigia e censura. Como afirmou Sonia de Mancera:

(...) o bêbado não diz o que se espera que diga, o que é previsível, o que a autoridade quer ouvir, senão aquilo que desejou expressar à margem do que é aceito e permitido. Não faz o que é correto, senão aquilo que deseja fazer. Neste sentido, o riso é a perfeita e maravilhosa loucura da liberdade. ${ }^{26}$

Será de posse desta visão da embriaguez, como "loucura da liberdade", liberdade que deveria ser reprimida ao ponto da sujeição e da redução, que os religiosos se irão relacionar com a "loucura" tupinambá. Relação sempre perigosa: aos jesuítas, e a outros missionários (como os capuchinhos franceses do Maranhão), as cauinagens pareciam uma verdadeira "traça de infierno", ${ }^{27}$ um ritual demoníaco e relacionado ao canibalismo e à imundície, que colocava em risco a própria vida dos missionários, que jamais se sentiam seguros

(...) entre gente que a nada sabe ter respeito nem obediencia, e que quasi sempre anda quente de vinho, no qual gastavam os mais dos dias bebendo e cantando todo o dia e noite, com grandes gritos, homens e mulheres mistura-

\footnotetext{
${ }^{25}$ Apud Mancera, 1991, op. cit., p. 27.

${ }^{26}$ Mancera, 1994, op. cit., p. 45.

${ }^{27}$ Carta do Pe. Luís da Grã ao Pe. Inácio de Loyola, Roma (Bahia, 27/12/1554), Leite, 1954, op. cit., v. II, p. 132-133.
} 
dos, de maneira que, nem em casa nem fóra podiamos estar sem ouvir e ver suas borracharias. ${ }^{28}$

Esta falta de ordem, este afastamento da razão, da moderação e do "termo médio", que tanto aborrecia aos religiosos, é uma constante nas descrições das cerimônias etílicas dos índios no Brasil. Fernão Cardim, por exemplo, aponta a confusão reinante durante as cauinagens voltadas ao sacrifício canibal, quase que mostrando um horror maior ao barulho e ao comportamento dos índios quando bebiam do que ao próprio ato de comer o inimigo aprisionado:

A este tempo estão os potes de vinho postos em carreira pelo meio de uma casa grande, e como a casa não tem repartimentos, ainda que seja de 20 ou 30 braças de comprido, está atulhada de gente, e tanto que começão a beber é um lavarinto ou inferno ve-los e ouvi-los, porque os que bailão e cantão aturão com grandissimo fervor quantos dias e noites os vinhos durão: porque, como esta é a propria festa das matanças, ha no beber dos vinhos muitas particularidades que durão muito, e a cada passo ourinão, e assim aturão sempre, e de noite cantão e bailão, bebem e fallão cantando em magotes por toda a casa, de guerras e sortes que fizerão, e como cada um quer que lhe oução a sua historia, todos fallão a quem mais alto, afora outros estrondos, sem nunca se calarem, nem por espaço de um quarto de hora. ${ }^{29}$

Os capuchinhos franceses do Maranhão também se horrorizaram com a folie etílica dos índios brasileiros e descreveram suas cauinagens em cores vívidas, apontando em especial o caráter orgíaco destas cerimônias. Foi este o caso de Yves d'Evreux, que dizia ser

(...) horrível espetáculo ver essas gentes em reuniões, parecendo antes congresso noturno de feiticeiros do que ajuntamento de homens. Achei-me apenas uma só vez nestas reuniões, para deles poder falar, e nunca mais lá tornei. Via aqui uns deitados em suas redes vomitando com muita força, outros(s) caminhando ou marchando em diversos sentidos com o juízo perdido pelo vinho, ali outros gritando, fazendo mil trejeitos, estes dançando ao som do maracá, aqueles bebendo com muito boa vontade, aqueloutros fumando para mais se embriagarem, e o que é ainda pior é estarem mulheres e moças aí misturadas, parecendo bem difícil a presença de Baco sem Vênus. ${ }^{30}$

\footnotetext{
${ }^{28}$ José de Anchieta, “Ao Geral Diogo Lainez, de São Vicente, janeiro de 1565”, José de Anchieta, Cartas, informações, fragmentos históricos e sermões, Belo Horizonte, Itatiaia/São Paulo, Edusp, 1988, p. 223.

${ }^{29}$ Fernão. Cardim, Tratados da Terra e Gente do Brasil, São Paulo/Brasília, Companhia Ed. Nacional/INL, 1978 (1 ${ }^{a}$ edição: 1625), p. 116.

${ }^{30}$ Yves d' Evreux, Viagem ao norte do Brasil feita nos anos de 1613 a 1614, $3^{\text {a }}$ edição, São Paulo, Siciliano, 2002 (1 $1^{\text {a }}$ edição: 1615), p. 275-276.
} 
O companheiro de Evreux, Claude d'Abbeville, também se impressionou fortemente, ao ver os sátiros e as mênades da América executarem suas tropelias, ao sabor do cauim e do tabaco e ao som dos maracás:

Nunca senti tamanho espanto como quando entrei numa dessas cabanas onde estava havendo uma cauinagem; no primeiro plano se achavam êsses grandes vasilhames de barro cercados de fogo e com a bebida fumegando; mais adiante, inúmeros selvagens, homens e mulheres, alguns completamente nus, outros descabelados, outros ainda revestidos de penas multicores, uns deitados expirando a fumaça do tabaco pela bôca e pelas narinas, outros dançando, saltando, cantando e gritando. E todos tinham a cabeça enfeitada e a razão tão perturbada pelo cauim que reviravam os olhos a ponto de parecer encontrarme em presença de símbolos ou figuras infernais. E se na verdade o Diabo se deleita na companhia de Baco e busca por meio da dança perder as almas, há de por certo comprazer-se infinitamente nas reuniões desse miserável povo, que sempre lhe pertenceu pela barbárie, pela crueldade e embriaguez, e que somente encontra satisfação em dançar e cauinar quando se apresenta uma oportunidade, durante dois a três dias seguidos, sem repouso nem para dormir, até que todos os potes se esvaziem. ${ }^{31}$

As referências ao deus Baco não deixam de ser sintomáticas. Afinal, o que faziam os participantes das cauinagens, tal como faziam os das órguias helênicas, ou das bacchanalia romanas (tão atacadas pelos primeiros cristãos), era atingir o enthūsiasmós, mas não "trazendo o deus para dentro", como aqueles, já que não havia qualquer Deus a trazer, como apontaram os próprios missionários. No enthūsiasmós tupinambá buscava-se o aligeiramento, a leveza do corpo (por meio, por exemplo, dos vômitos, muito mal vistos pelos observadores, ou da extenuação provocada pelas danças intermináveis) e, mais do que tudo, o escapar - ao menos por algumas horas - de uma humanidade que era uma condição temporal, e não uma essência, ou uma natureza. ${ }^{32}$

Os missionários perceberam muito bem que os índios, ao se embriagarem de forma tão aparentemente louca, deixavam de ser homens, e o fato de que pensassem que aqueles se tornavam demônios (ou bestas), e não deuses (ao contrário do que pensavam os próprios tupinambás), em nada altera a perspicácia (em vista de seus próprios fins) de seu olhar. Para inverter o sentido da transformação provocada pela embriaguez - de demônios para homens, mas

${ }^{31}$ Claude d'Abbeville, História da Missão dos Padres Capuchinhos na Ilha do Maranhão e terras circunvizinhas, $3^{\mathrm{a}}$ edição, Belo Horizonte, Itatiaia/São Paulo, Edusp, 1975 (1 $1^{\mathrm{a}}$ edição: 1614), p. 239.

${ }^{32}$ Viveiros de Castro, op. cit., p. 205 e 256. 
homens reduzidos e sujeitos - era necessário combater as cauinagens, aquele "templo" virtual, líquido e espumante dos selvagens.

$\mathrm{Na}$ luta contra o pecado mortal da intemperança alcoólica, os vários missionários, e mais ainda os jesuítas, tiveram que se haver com os problemas trazidos pelos colonos leigos. Era fundamental separar os nativos da má influência destes colonos, sem o que a missionação seria uma tarefa mais do que hercúlea, e até impossível. Entre estes problemas, não era o menor o fato de que os índios, de posse dos instrumentos de ferro fornecidos pelos europeus, melhoraram substancialmente a eficiência de seu trabalho, e sua capacidade de intervenção em seu ambiente.

Este aumento de eficiência permitiu que o jesuíta Pero Correia criticasse os hábitos etílicos dos nativos com base em uma generalização de cunho universalizante, ao afirmar, em 1553, que os índios "tienen las casas llenas de heramientas", o que lhes permitia ter as roças que quisessem, com resultados diretos na ocorrência das cauinagens e das guerras: "aora (...) comen y beben de continuo, y ándanse siempre a beber binos por las aldeas, ordenando gueras y hazie(n)do muchos males, lo que hazen todos los que son muy dados al vino por todas las partes del mundo". O inaciano propunha que se parasse de dar instrumentos e ferramentas aos índios, para que dessem obediência a quem as tivesse, "y a conocer señorio", voltando aos tempos em que era "la hambre tanta entre ellos, que morían de hambre e vendían un sclavo por una cuña (...), y también vendían los hijos y hijas, y ellos mismos se entregavan por sclavos". ${ }^{33}$

Seria nos aldeamentos - espaço que, ao menos idealmente, estava localizado além do saculum - que os jesuítas construiriam sua estratégia de luta contra as cauinagens. É bem verdade que os aldeamentos não estavam alheios à lógica do sistema colonial, mantendo-se permanentemente em uma posição ambígua quanto ao conflito entre jesuítas e colonos. ${ }^{34}$ De um lado, a própria Companhia de Jesus, por meio de seus superiores em Roma, nutria sérias dúvidas quanto à conveniência de que a administração temporal das aldeias ficasse em mãos inacianas, e de que os missionários ficassem tão expostos aos perigos do convívio íntimo com os índios (e especialmente com as

\footnotetext{
${ }^{33}$ Carta do Ir. Pero Correia [ao Pe. Simão Rodrigues, Lisboa] (S. Vicente, 10/03/1553), Leite, 1954, op. cit., v. I, p. 445-446; sobre este tema, ver John M. Monteiro, Negros da Terra: indios e bandeirantes nas origens de São Paulo, São Paulo, Companhia das Letras, 1994, p. 30-31.

${ }^{34}$ Maria R. Celestino de Almeida, Metamorfoses Indigenas: Identidade e cultura nas aldeias coloniais do Rio de Janeiro, Rio de Janeiro, Arquivo Nacional, 2003, p. 103.
} 
índias), enquanto os jesuítas no Brasil tinham toda a certeza de que somente assim sua missão seria bem-sucedida. ${ }^{35}$

De outro lado, os aldeamentos representavam uma instituição crucial para a boa ordem do sistema colonial, na medida em que cumpriam a função básica de "civilizar" os índios e torná-los obedientes vassalos da Coroa. ${ }^{36}$ Além disto, os índios aldeados, e sujeitos, representavam uma verdadeira "polícia" (no sentido moderno do termo) do sistema, como afirmou um jesuíta anônimo: “(...) porque elas assombram aos inimigos estrangeiros, fazem rosto aos aimorés, refocão (sic) aos negros da Guiné que se não levantem, e aos salteadores dos caminhos e fugitivos tomam e prendem e os entregam aos seus senhores (...)". ${ }^{37}$

De todo modo, o fato de que o poder interno aos aldeamentos estivesse adscrito aos inacianos lhes permitiu impor regras rígidas quanto ao uso das bebidas fermentadas nativas, pelo menos no que diz respeito ao seu consumo na forma de cauinagens: afinal, o que se queria impedir eram as cerimônias e os riscos associados a elas, e não o consumo moderado de bebidas que "eram o seu sustento". Não foi algo fácil, especialmente por conta da resistência daqueles indivíduos mais comprometidos com as "gentilidades", geralmente os anciãos das aldeias, velhos guerreiros de corpos riscados (que já haviam matado e comido muitos inimigos), e velhas "feiticeiras", que já haviam mascado muita mandioca (ou milho) e fabricado muito cauim para os "congressos noturnos".

Estas velhas incomodaram muito os jesuítas e colocaram inúmeros obstáculos à repressão às cauinagens, o que não deve surpreender, tendo em vista que toda a produção dos cauins era uma atividade profundamente relacionada às mulheres. Além disto, estas velhas podiam ocupar importantes posições de poder dentro do mundo indígena, ${ }^{38}$ como revela esta carta do inaciano Antônio Blázquez, acerca de seu trabalho nas aldeias do Recôncavo baiano:

Huma hora antes do sol, se toca outra vez a campainha pera que venhão as velhas e velhos que em estremo são preguisosos, aos quais torna outra vez a ensinar a doutrina. A estas trabalha o Irmão polas ter mais benevolas porque as Aldeas regem-se cá polas velhas feiticeiras e com ellas se toma o conselho da guerra, e se ellas quisessem persuadir aos mais a que viessem à doutrina,

\footnotetext{
${ }^{35}$ Pompa, op. cit., p. 73.

${ }^{36}$ Almeida, op. cit., p. 101-109.

${ }^{37}$ Anônimo, Algumas advertências para a província do Brasil (1609?), apud Pompa, idem, p. 74 .

${ }^{38}$ João A. Fernandes, De Cunhã a Mameluca: A Mulher Tupinambás e o Nascimento do Brasil, João Pessoa, Ed. UFPB, 2003, p. 32-34.
} 
sem duvida que se fizesse mais proveyto e ouvera mais numero de indios, mas hé tudo polo contrario, que totalmente estrovão a que não ousão a doutrina e siguão nossos custumes, e por isso se tem quaa por averiguado que trabalhar com ellas hé quasi em vão (..... ${ }^{39}$

Os tenazes padres não se intimidavam com estas resistências, colocando claramente para os índios que não havia acordo possível entre a aceitação do cristianismo (ou o que quer que esta "aceitação" significasse para os nativos) e determinadas práticas, como o canibalismo, a nudez, a poliginia e, por certo, as bebedeiras. Um bom exemplo deste tipo de imposição é dado pela chegada dos jesuítas à aldeia de Santo Antônio, em Arembepe, na Bahia. Escrevendo aos padres e aos irmãos de Portugal, o padre Antônio Pires informava que os índios daquela localidade há muito esperavam que os inacianos os visitassem, o que foi feito quando o provincial Luis da Grã inspecionou as aldeias daquela região, em 1560.

Pires informa que os nativos receberam os padres da mesma forma "como custumavão fazer em outro tempo a seus feiticeyros", colocando "huma ramada com sua rede para o Padre descansar e comer". O principal da aldeia, um "senhor da fala" como costumavam ser os chefes tupinambás, discursava em sua honra, dizendo: "vinde, muyto folgo com vossa vinda, alegro-me muyto com isto; os caminhos folgão, as hervas, os ramos, os passaros, as velhas, as moças, os meninos, as agoas, tudo se alegra, tudo ama a Deos".

Muito enternecidos com tal recepção, mas muito práticos em seus objetivos, os padres logo trataram de impor suas exigências para "deixar aly quem os doutrynasse". Luis da Grã informou aos principais "os pontos mais essentiais que avião de goardar", e entre eles estavam:

(...) que ninguem avya de ter mais [de huma molher], e outro que não avião de beber até se embebedar [como cus]tumavão, e que não avião de consentir os feiticeyros, e que avião todos de aprender, e que não avião de matar nem comer carne humana: isto foy supérfluo porque já o eles agora não fazem.

Embora surpresos em perceber os índios tão dispostos a abandonar "semelhantes cousas", fato que, anteriormente, consideravam "a mayor impossibilidade do mundo", os padres ficaram muito satisfeitos em ver que a aceitação das exigências ia ao ponto de os nativos quererem "comprir toda a ley que lhe puserem", inclusive levantando "tronquo para castiguo dos roins". Afoitos para

${ }^{39}$ Quadrimestre de setembro de 1556 a janeiro de 1557 pelo Ir. Antonio Blázquez (?) (Bahia, 01/01/1557), Leite, 1954, op. cit., v. II, p. 352. 
ganhar o apreço dos jesuítas, alguns dos principais, no papel de "meirinhos", foram logo "à cidade (...) para terem cuydado de prenderem os roins". ${ }^{40}$

Conceder a alguns dos índios mais importantes, e mais cooperativos, o papel de meirinhos representou uma das estratégias mais úteis no sentido de atrair apoios entre os principais nativos. Afinal, os índios eram bastante sensíveis à concessão de honrarias por parte dos europeus, mesmo que estas fossem de valor irrisório. Em carta a El-Rei D. Sebastião, datada de 31 de março de 1561, o governador-geral Mem de Sá informava que havia nomeado, na Capitania do Espírito Santo, "um meirinho dos do gentio em cada vila, porque folgam eles muito com estas onrras e contentam-se com pouco: com os vestirem cad'anno e às molheres huma camisa d'algodam bastará". O objetivo do governador era, justamente, auxiliar a catequese dos jesuítas, ao

(...) fazer tronco em cada vila e pelourinho, por lhes mostrar que tem tudo o que os cristãos tem, e para o meirinho meter os moços no tronco quando fogem da Escola (...) com autoridade [de] quem os ensina ${ }^{41}$ e riside na vila. D[isto] são muito contentes, e recebem milhor o castigo que nós". ${ }^{42}$

Nem todos os índios nomeados como meirinhos pareciam compreender totalmente o alcance de suas responsabilidades, pelo menos do ponto de vista dos jesuítas. Era o caso do principal da Vila de São João, na Bahia, que, apesar de ter sido nomeado meirinho, "não ajudava, mas estorvava e desobedecia muytas vezes ao Governador e aos Padres", especialmente por continuar a fazer guerra contra os inimigos. ${ }^{43}$ Era o que ocorria também com os "novamente christianos" (recém- convertidos) Garcia de Sá e Bastião de Ponte, meirinhos em aldeias na Bahia, a respeito dos quais o Irmão Antonio Rodrigues pedia a Manuel da Nóbrega que os obrigassem a se por em "órden y policia christiana". ${ }^{4}$

Outros, porém, exerciam com eficiência o papel que lhes havia sido destinado, entre eles o "alcaide" de Piratininga, mencionado por Anchieta, que

${ }^{40}$ Carta do Pe. António Pires aos Padres e Irmãos de Portugal ([Aldeia de Santiago] Bahia, 22/10/1560), Leite, 1954, op. cit., v. III, p. 312-313.

${ }^{41}$ Isto é, os padres da Companhia: Leite, idem, v. III, p. 172, nota 9.

${ }^{42}$ Carta de Mem de Sá, Governador do Brasil, a D. Sebastião, Rei de Portugal (Rio de Janeiro, 31/03/1560), Leite, ibidem, v. III, p. 172.

${ }^{43}$ Carta do Pe. Manuel da Nóbrega ao Pe. Miguel de Torres e Padres e Irmãos de Portugal (Bahia, 05/07/1559), Leite, 1954, op. cit., v. III, p. 59.

${ }^{44}$ Carta do Ir. António Rodrigues ao Pe. Manuel da Nóbrega, Baía ([Aldeia do Espírito Santo] Bahia, 08[?]/08/1559), Leite, idem, v. III, p. 122. 
obrigava os índios a entrar na Igreja para ouvir a pregação dos padres. ${ }^{45}$ Nenhum deles, contudo, se mostrou mais disposto a auxiliar os jesuítas no combate aos vinhos da terra do que Urupemaíba, principal da Aldeia do Espírito Santo (Bahia), o qual, como afirmava Antonio Rodrigues, era "muy buen yndio", e que sempre vinha "com los braços abiertos abraçarme, diziendo que siempre nos avía favorecido y que siempre lo avía de hazer". ${ }^{66}$ Ainda que Urupemaíba não tivesse "a vara" - ou seja, não tivesse sido oficialmente nomeado - mas "solamente la esperança de lo ser" (ou, talvez, justamente por isso...), foi um dia com um martelo

(...) a la media noche y quebró quantas tinajas halló llenas de vino, porque se tiene mandado que no bevan de noche por se evitar muchas occasiones de peccados y disoluciones que entonces se hazen. De todo sale mucho loor al Señor. Que será después que el Governador le hiziere la solennidad devida?47

É claro que não se poderia contar apenas com o concurso de alguns principais mais dispostos a auferir vantagens de suas relações privilegiadas com os padres da Companhia ou com as autoridades laicas. Para a peleja contra uma estrutura tão central na vida dos tupinambás, como eram os cauins e as cauinagens, era fundamental que as noções de moderação e temperança e a idéia de que a embriaguez voluntária constituía um pecado fossem divulgadas e praticadas para a sociedade como um todo, alcançando-se aquele estado de coisas que o padre Leonardo Nunes percebia, ou imaginava existir, entre os Guarani (carijós), os quais não bebiam

vino hasta emborracharse como éstos (os tupinambás), antes uma Aldea bebe um solo cántaro o dos de vino, y esto raramente, lo que es gran cosa, porque el mucho bever destes es cousa de muchos males, como ya V. R. ${ }^{a}$ terná experimentado. ${ }^{48}$

Era necessário fazer algo mais. Os inacianos precisavam atingir - com sua pregação, ou com outras formas de pressão - as mulheres, para as quais eram os cauins uma instância central na obtenção de prestígio e honra. ${ }^{49}$ Parece-me,

\footnotetext{
${ }^{45}$ Ao Geral Diogo Lainez, de São Vicente, a 16 de abril de 1563, Anchieta, op. cit., p. 196.

${ }^{46}$ Carta do Ir. António Rodrigues ao Pe. Manuel da Nóbrega, Baía ([Aldeia do Espírito Santo] Bahia, 08[?]/08/1559), Leite, ibidem, v. III, p. 122.

${ }^{47}$ Carta do Ir. António Rodrigues ao Pe. Manuel da Nóbrega, Baía ([Aldeia do Espírito Santo] Bahia, 09[?]/08/1559), Leite, ibidem, v. III, p. 126.

${ }^{48}$ Carta do Pe. Leonardo Nunes ao Pe. Manuel da Nóbrega, Baía (S. Vicente, 29/06/1552), Leite, 1954, op. cit., v. I, p. 340.

${ }^{49}$ João A. Fernandes, op. cit., p. 30-41.
} 
aliás, que o sucesso dos jesuítas em obter a colaboração das mulheres nesta missão representou um de seus logros mais extraordinários: tomando de empréstimo o que disse Eduardo Viveiros de Castro a respeito do abandono do canibalismo, poderíamos dizer que o abandono das cauinagens representou "uma derrota, sobretudo, da parte feminina da sociedade tupinambá". ${ }^{0}$ É um sucesso que se inscreve em um movimento mais amplo, que fez das mulheres um dos esteios mais importantes da ação jesuítica. ${ }^{51}$

Ora, se foi importante para os jesuítas contar com principais ambiciosos, mais ainda o foi atrair o apoio de mulheres e meninos, como apontou, com agudeza, o provincial Luís da Grã, em carta ao próprio Inácio de Loyola: “de los niños tenemos mucha esperança, porque tienen habilidad y ingenio, y tomados ante que vaian a la guerra, ado van y aún las mugeres, y antes que bevan y entiendan em desonestidades". ${ }^{52}$ Eram mulheres como aquelas descritas por Anchieta que escondiam os vasos em que os índios comiam e bebiam "porque não usem deles as outras", quando se preparavam para matar e comer algum inimigo ${ }^{53}$. E, o que é ainda mais importante, as mulheres cristãs permitiam que seus filhos fossem levados (seqüestrados, diria Viveiros de Castro) ${ }^{54} \mathrm{e}$ internados nos colégios dos padres, onde a visão de embriaguez como pecado lhes pudesse ser inculcada.

Acertaram em cheio os jesuítas, ao atacar justamente as clivagens centrais da sociedade tupinambá, que envolviam as diferenças de idade e de gênero. Construída pela e para a guerra, enquanto mecanismo de criação de memórias e de temporalidades, a sociedade tupinambá reservava um lugar necessariamente subalterno aos jovens e às mulheres, pelo menos nos discursos dominantes, os quais, no fim das contas, fundavam o próprio ser tupinambá.

A centralidade da guerra fazia com que, em relação aos jovens, esta clivagem fosse provisória e superável pela proeza guerreira. Desta forma, os relatos dos jesuítas oscilavam permanentemente entre o entusiasmo e a esperança na conversão dos meninos, e a desilusão e o desânimo ao ver que, assim que se tornavam adultos, os doces catecúmenos se tornavam tão "selvagens" quanto seus pais. O próprio Luís da Grã, apenas dois anos após manifestar

\footnotetext{
${ }^{50}$ Viveiros de Castro, op. cit., p. 259.

${ }^{51}$ João A. Fernandes, op. cit., p. 253-264.

${ }^{52}$ Carta do Pe. Luís da Grã ao Pe. Inácio de Loyola, Roma (Bahia, 27/12/1554), Leite, 1954, op. cit., v. II, p. 133.

${ }_{53}^{53}$ Ao Geral Diogo Lainez, de São Vicente, janeiro de 1565, Anchieta, op. cit., p. 211.

${ }^{54}$ Viveiros de Castro, op. cit., p. 261.
} 
suas esperanças na conversão dos meninos, reconhecia que o otimismo havia sido exagerado:

(...) sus contritiones, sus desseos de seren buenos, todo es tan remisso, que no puede hombre certificar del. Lãs mugeres tienen más biveza en ello y mucho más se aplican a lo bueno, los hombres hasta 18 y 20 annos dan buena muestra, dende adelante comiençan a bever y házense tan rudos y tan ruínes que no es de creer. Este es el peccado de que parece menos se emendarán, porque mui poco es el tiempo que no estén beodos, y en estos vinos, que ellos hazen de todalas cosas, se tratan todalas malicias e deshonestidades (...). ${ }^{55}$

Apesar dos percalços, o grande alvo da ação jesuítica sempre esteve voltado para os meninos, cuja plasticidade permitia que trafegassem com maior facilidade entre os diferentes códigos culturais, e cuja imaturidade social - não mataram inimigos, logo não podiam beber - permitia aos jesuítas atingir um público "virgem" dos prêmios concedidos pela sociedade tupinambá aos seus heróis, como a honra de serem considerados principais, os riscos no corpo ou a poliginia. ${ }^{56}$ Desde os primeiros anos, os inacianos trataram de "enseñarlos a ler y a escrevir, y a algunos dellos a cantar", pressionando todo aquele que fosse "perezoso" a ir para a escola. Diz Pero Correia que alguns dos meninos eram "tan vivos y tan buenos y tan atrevidos, que quiebran las tinajas llenas de vino a los suyos para que no bevan". ${ }^{57}$

Alguns destes meninos, comemorava Anchieta, eram "bem instruidos em leitura, escrita e em bons costumes", abominando "os usos de seus progenitores". Meninos que, com toda a certeza, auxiliavam os jesuítas na censura à "fraqueza" da conversão de seus pais, já "mui diferentes nos costumes dos de outras terras", mas sempre sujeitos a recaídas, como aqueles que foram a uma terra vizinha de Piratininga, onde havia um festim canibal, "não para comer carne humana, mas por beber e ver a festa", após o que tiveram que ser "disciplinados" para poderem voltar a entrar na igreja. ${ }^{58}$

Bastaram cinco anos para Anchieta cair na realidade e perceber que as "gentilidades" tinham razões que a temperança e a "polícia" desconheciam.

\footnotetext{
${ }^{55}$ Carta do Pe. Luís da Grã ao Pe. Inácio de Loyola, Roma (Piratininga, 08/06/1556), Leite, 1954, op. cit., v. II, p. 294.

${ }^{56}$ Sobre a estratégia jesuítica em relação aos meninos, cf. Plínio F. Gomes, "O ciclo dos meninos cantores (1550-1552): música e aculturação nos primórdios da colônia”, Revista Brasileira de História, vol. 11, no 21, São Paulo, 1990-1991, p. 187-198.

${ }^{57}$ Carta do Ir. Pero Correia [ao Pe. Brás Lourenço, Espírito Santo] (São Vicente, 18/07/1554), Leite, idem, v. II, p. 70.

${ }^{58}$ Carta de São Vicente, a 15 de março de 1555, Anchieta, op. cit., p. 89.
} 
Escrevendo em 1560, o missionário canarino era forçado a reconhecer que o trabalho de conversão teria que ser muito mais intenso, talvez exigindo o concurso mais incisivo do poder temporal e o afastamento mais radical dos colonos:

Dos moços que falei no princípio foram ensinados não só nos costumes Cristãos, cuja vida quanto era mais diferente da de seus pais, tanto maior ocasião dava de louvar a Deus e de receber consolação, não queria fazer menção por não refrescar as chagas, que parecem algum tanto estar curadas; e daqueles direi sòmente, que chegando aos anos da puberdade, começáram a apoderar-se de si, vieram a tanta corrupção, que tanto excedem agora a seus pais em maldade, quanto antes em bondade, e com tanta maior senvergonha e desenfreamento se dão ás borracheiras e luxurias, quanto com maior modestia e obediencia se entregavam dantes aos costumes Cristãos e divinas instruções. Trabalhamos muito com eles, para os reduzir ao caminho direito, nem nos espanta esta mudança, pois vemos os mesmos Cristãos procederem da mesma maneira. ${ }^{59}$

Os mesmos meninos nos quais "se fazia algum fruto" estavam agora "totalmente remetidos aos seus antigos e diabolicos costumes, exceto o de comer carne humana", mas fazendo "grandes festas na matança dos seus inimigos" e "bebendo grandes vinhos como antes eram acostumados", juntamente com seus pais. ${ }^{60}$ Quando bêbados e "enraivecidos", provavelmente agiam como os índios não convertidos, que "passavam por nós outros sem nos falar, nem olhar senão de través, como homens que não nos conheciam, e assim todas as noites, maximè quando bebiam e cantavam (...)" ${ }^{61}$

Com a persistência das vinhaças, os jesuítas não se arriscavam apenas a sofrer violências físicas, para as quais, verdade seja dita, estavam psicologicamente muito bem preparados. Mais sérios eram os riscos para a ortodoxia religiosa. Embora os índios se mostrassem quase sempre bem dispostos a ouvir as pregações, parecia aos padres que os vinhos lhes turvavam a compreensão do que lhes era dito. "Holgavan de oyrlas" disse Azpilcueta Navarro, "mas luego se les olvidan, mudando el sentido en sus vinos y guerras". ${ }^{2}$

Mais do que apenas lamentar os equívocos dos índios, preocupavamse os inacianos com a proliferação das caraimonhagas, ou santidades, ritos

\footnotetext{
${ }^{59}$ Ao Padre Geral, de São Vicente, a $1^{\circ}$ de junho de 1560, Anchieta, idem, p. 166.

${ }^{60}$ Ao Padre Geral Diogo Lainez, de São Vicente, a 12 de junho de 1561, Anchieta, ibidem, p. 176.

${ }^{61}$ Ao Geral Diogo Lainez, de São Vicente, janeiro de 1565, Anchieta, op. cit., p. 239.

${ }^{62}$ Carta do Pe. Juan de Azpilcueta Navarro aos Padres e Irmãos de Coimbra (Porto Seguro, 24/06/1555), Leite, op. cit., v. II, p. 248.
} 
relacionados às atividades dos pajés itinerantes, os caraíbas, "feiticeiros" que inventavam "bailes e cantares novos" e que faziam os índios "beber e bailar todo o dia e noite, sem cuidado de fazerem mantimentos", dizendo "que as velhas se hão de tornar moças", ${ }^{63}$ prometendo abundância, sucesso militar e o fim das doenças, entre outras coisas que perturbavam grandemente o bom andamento do proselitismo jesuítico, ${ }^{64}$ muito embora os índios dedicassem aos caraíbas a mesma falta de firmeza e de constância que mostravam pelos dogmas cristãos: “(...) no hai en esta tierra idolatria, sino ciertas sanctidades que ellos dizen que ni creen ni dexan de creer" ${ }^{65}$

Apesar deste laxismo dos índios quanto a seus "santos", é fato que os caraíbas gozavam de enorme prestígio, ${ }^{66}$ sendo considerados como grandes "heróis" (os heróis culturais míticos, detentores do conhecimento xamânico, eram também chamados de karaiba) ${ }^{67} \mathrm{e}$ "senhores da fala", o que fazia com que os nativos lhes proporcionassem - e aos seus "ídolos", os maracás - grandes festas e "muchos cantares (...) biviendo muchos vinos assi hombres como mugeres, todos juntos, de día y de noche, haziendo harmonías diabólicas". ${ }^{68}$

Sendo também os jesuítas "senhores da fala", foram logo identificados, e buscaram identificar-se, com eles: os padres também discursavam pelas madrugadas e prometiam abundância e vitória sobre os inimigos, além de curar (ou tentar curar) suas doenças, muitas vezes trazidas por eles próprios. Mais interessante ainda do que esta "conversão" dos jesuítas às práticas dos caraíbas, contudo, foi o movimento contrário: a aceitação por parte destes de partes e imagens do discurso e da liturgia cristã, fenômeno de que a Santidade do Jaguaripe, estudada por Ronaldo Vainfas, foi o exemplo mais extraordinário, embora não o único.

Sem querer repetir aqui os argumentos e as conclusões de Ronaldo Vainfas ou de Cristina Pompa, entre outros, acerca da Santidade do Jaguaripe - religião híbrida que floresceu por volta de 1585, e cujas informações nos chegaram, basicamente, por meio da documentação inquisitorial - é importante apontar, como fez Vainfas, que as festas à moda nativa representavam o

${ }^{63}$ José de Anchieta, "Informação do Brasil e de suas Capitanias - 1584", Anchieta, idem, p. 339.

${ }^{64}$ Cf. Vainfas, op. cit.; Pompa, op. cit..

${ }^{65}$ Carta do Pe. Luís da Grã ao Pe. Inácio de Loyola, Roma (Piratininga, 08/06/1556), Leite, idem, v. II, p. 292.

${ }^{66}$ Vainfas, op. cit., p. 61.

${ }^{67}$ Viveiros de Castro, op. cit., p. 202.

${ }^{68}$ Carta do Ir. Pero Correia [ao Pe. João Nunes Barreto, África] (S. Vicente, 20/06/1551), Leite, 1954, op. cit., v. I, p. 225. 
centro do culto mestiço ao ídolo Tupanasu, que se realizava em terras baianas. Não obstante, e talvez por conta do viés da documentação - depoimentos de indivíduos mais do que dispostos a apagar suas culpas e diminuir o número de seus pecados - os cauins estão singularmente ausentes. As descrições dos rituais da caraimonhaga do Jaguaripe são extremamente vagas e genéricas.

Se nos ativermos, contudo, à documentação, é forçoso reconhecer que, na mistura entre elementos da cultura tupinambá e da liturgia cristã, o papel do tabaco foi grandemente inflado, às expensas das bebidas fermentadas. É possível que a "derrota da parte feminina da sociedade", expressa na progressiva perda de prestígio das cauinagens, tenha chegado ao ápice quando os caraíbas assumiram (embora por pouco tempo) o papel dos misóginos "padres", colocando aquilo que era um apanágio dos xamãs nativos, o uso do tabaco, como o foco central do rito.

Em sua arguta análise do papel do petum nas santidades, Ronaldo Vainfas mostra que aquela configuração cultural específica que se construiu no Jaguaripe foi mais importante do que qualquer potencialidade "neurológica" das substâncias essenciais envolvidas no ritual da Santidade, e esta configuração não parece ter dedicado um papel relevante às cauinagens. $O$ veículo religioso privilegiado daquele culto foi, de fato, o tabaco: "mais do que embriagante, o fumo da santidade era divino, conforme exclamou, com fervor, certo adepto da seita: 'Bebamos o fumo, que este é o nosso Deus que vem do Paraíso"'. ${ }^{69}$

Conforme disse antes, é possível que a ausência dos cauins esteja relacionada a um determinado viés documental. O jesuíta Fernão Guerreiro, escrevendo em 1609, dizia, a respeito de outra santidade, que os índios andavam "tão cegos com aquela que chamam a sua santidade, que totalmente teem para si que não há outra e que eles só são os que acertam (...). Usam da cruz, mas com pouca reverência, e teem outras cerimonias ao modo da igreja (...)”. A demonstração mais cabal de que o cristianismo era "lido" de forma totalmente idiossincrática pelos nativos era o discurso do "padre" desta santidade: "ele estava como quem ensina a doutrina, misturando mil desbarates, como era dizer Santa Maria, tupana, remireco, que quer dizer Santa Maria, mulher de deus, e outros despropósitos semelhantes". ${ }^{70}$

É difícil imaginar que nestas "cerimonias ao modo da igreja" não se imitasse, com o uso dos cauins, o papel do vinho como o "sangue" do Cristo, mas este é um vôo especulativo que a falta de lastro documental me impede

${ }^{69}$ Vainfas, op. cit., p. 135-137.

${ }^{70}$ Apud Pompa, op. cit., p. 54. 
de fazer. Infelizmente não temos, para a missionação entre os tupinambás, elementos documentais que apontem casos semelhantes ao do cacique Guarani Miguel Atiguaye, que se fazia de padre, vestindo roupa branca e "mitra" de penas, e bebendo a chicha de milho em uma cabaça multicolorida. ${ }^{71}$ No que diz respeito aos primeiros índios a sofrerem o impacto da expansão portuguesa, o papel social e cultural das bebidas fermentadas parece ter diminuído conforme a colonização lusa se estabilizava e os aldeamentos da Companhia de Jesus atingiam seus objetivos.

Ao se encerrar o primeiro século da colonização, o discurso dos jesuítas acerca da embriaguez dos tupinambás já era bem mais otimista. Descrevendo, em 1584, a situação dos índios das aldeias, Fernão Cardim dizia: “(...) honram-se muito de chegarem a commungar, e por isso fazem extremos, até deixar seus vinhos a que são muito dados, e é a obra mais heróica que podem fazer (...)", ${ }^{2}$ enquanto Anchieta, em 1585, dizia que os índios deixavam com facilidade "os costumes depravados" como o de "embriagar-se de ordinario com os vinhos". ${ }^{3}$ O nome de José de Anchieta, aliás, ficará marcado indelevelmente como o maior e mais tenaz inimigo das cauinagens, especialmente por conta de seu Auto de São Lourenço, ${ }^{74}$ notável peça teatral em que todos os preconceitos dos padres contra os vinhos da terra, e todos as estratégias utilizadas para desmoralizar os adeptos das cerimônias etílicas foram utilizados.

No auto, os principais personagens são Guaixará - chefe Tamoio de Cabo Frio, que atacou os portugueses em 1566-1567 - que é identificado ao Diabo e seus dois auxiliares, Aimbirê e Saravaia. Guaixará inicia seus discursos reclamando da chegada dos jesuítas à sua terra e se apresentando como campeão dos "maus costumes" dos tupinambás:

Esta virtude estrangeira / Me irrita sobremaneira. / Quem a teria trazido, / com seus hábitos polidos / estragando a terra inteira? (...) / Quem é forte como eu? / Como eu, conceituado? / Sou diabo bem assado. / A fama me precedeu; / Guaixará sou chamado. / Meu sistema é o bem viver. / Que não seja constrangido / o prazer, nem abolido. / Quero as tabas acender / com meu fogo preferido / Boa medida é beber / cauim até vomitar. / Isto é jeito de gozar / a vida, e se recomenda / a quem queira aproveitar.

\footnotetext{
${ }_{71}$ Maxime Haubert, Índios e Jesuítas no Tempo das Missões (Séculos XVII-XVIII), São Paulo, Companhia das Letras, 1990, p. 160.

${ }^{72}$ Cardim, op. cit., p. 191.

73 "Informação da Provincia do Brasil para nosso Padre (1585)", Anchieta, op. cit., p. 443.

${ }^{74}$ José de Anchieta, Auto representado na festa de São Lourenço, São Paulo, s.n’, 1948.
} 
A moçada beberrona / trago bem conceituada. / Valente é quem se embriaga / e todo o cauim entorna, / e à luta então se consagra. (...) / Vêm os tais padres agora / com regras fora de hora / prá que duvidem de mim. / Lei de Deus que não vigora.

As velhas que fabricavam o cauim, e que tantos problemas causaram aos inacianos, não foram esquecidas:

O diabo mal cheiroso, / teu mau cheiro me enfastia. / Se vivesse o meu esposo, / meu pobre Piracaê, / isso agora eu lhe diria.

Não prestas, és mau diabo. / Que bebas, não deixarei / do cauim que eu mastiguei. / Beberei tudo sozinha, / até cair beberei.

O diabo Guaixará envia seu auxiliar, Saravaia, para assolar as aldeias e aprisionar os índios que se haviam afastado da pregação cristã:

GUAIXARÁ

Demorou menos que um raio! / Foste mesmo, Saravaia?

\section{SARAVAIA}

Fui. Já estão comemorando / os índios nossa vitória.

Alegra-te! / Transbordava o cauim, / o prazer regurgitava. / E a beber, as igaçabas / esgotam até o fim.

\section{GUAIXARÁ}

E era forte?

\section{SARAVAIA}

Forte estava. / $\mathrm{E}$ os rapazes beberrões / que pervertem esta aldeia, / caiam de cara cheia. / Velhos, velhas, mocetões / que o cauim desnorteia.

São Sebastião chega à cena e pergunta aos demônios quem havia lhes dado o direito de comandar os índios:

\section{SÃO SEBASTIÃO}

Quem foi que insensatamente, / um dia ou presentemente? / os índios vos entregou? / Se o próprio Deus tão potente / deste povo em santo ofício / corpo e alma modelou! 
O auxiliar do Diabo, Aimbirê, responde, mostrando quem era o verdadeiro vilão, o verdadeiro instrumento da ação demoníaca entre os nativos:

\section{AIMBIRE}

Bebem cauim a seu jeito, / como completos sandeus / ao cauim rendem seu preito.

Esse cauim é que tolhe / sua graça espiritual. / Perdidos no bacanal / seus espíritos se encolhem / em nosso laço fatal. (...) / Têm bebida aos desperdícios, / cauim não lhes faltará. / De ébrios dão-se ao malefício, / ferem-se, brigam, sei lá!

Não faltam, também, novas recriminações contra as velhas "feiticeiras", que fabricavam os cauins e perturbavam, com seus feitiços, a cabeça e a sexualidade dos jovens, retirando-os da esfera de influência dos padres:

\section{GUAIXARÁ}

Eu que te ajude a explicar. / As velhas, como serpentes, / injuriam-se entre dentes, / maldizendo sem cessar. / As que mais calam consentem.

Pecam as inconseqüentes / com intrigas bem tecidas, / preparam negras bebidas / pra serem belas e ardentes / no amor na cama e na vida.

\section{AIMBIRE}

E os rapazes cobiçosos, / perseguindo o mulherio / para escravas do gentio... / Assim invadem fogosos... / dos brancos o casario.

O auto termina, como não poderia deixar de ser, de uma forma edificante, com Guaixará arrasado no inferno e com Aimbirê (que, na história real, se bandeou para o lado dos portugueses) atuando como algoz infernal dos imperadores romanos, Décio e Valeriano, perseguidores dos cristãos. Ironicamente, o inferno anchietano reunia índios e romanos, pecadores, os dois, por perseguirem e matarem os filhos de Deus, e pecadores, os dois, por fazerem da bebida e dos prazeres etílicos parte essencial de sua relação com o mundo e com a vida. Nos improvisados palcos das aldeias jesuíticas, representava-se toda a luta cristã contra o álcool e a embriaguez: reunia-se, a um só tempo, o princípio e o fim da história. Ali, em meio às matas brasileiras, o sonho milenarista de refundar o mundo se realizava, em meio à guerra contra a expansão da consciência e dos sentidos, e contra a liberdade e o riso, permitidos pela ebriedade. 